\title{
THE EFFECT OF DEBT EQUITY RATIO, RETURN ON EQUITY, NET PROFIT MARGIN ON STOCK PRICES
}

\author{
By \\ Ono Tarsono \\ Econimics College of Indonesia - Jakarta, Indonesia \\ Email: ono_tarsono@stei.ac.id
}

\begin{tabular}{|c|c|}
\hline Article Info & ABSTRACT \\
\hline $\begin{array}{l}\text { Article History: } \\
\text { Received:13-10-21 } \\
\text { Revised : } 16-11-21 \\
\text { Accepted: } 24-11-2021\end{array}$ & $\begin{array}{l}\text { This study aims to analyze DER, ROE, on stock prices on the Indonesia Stock } \\
\text { Exchange during the 2015-2019 period. The analytical research technique used is } \\
\text { multiple linear regression analysis. The results of this study indicate that the Debt } \\
\text { Equity Ratio, Return On Equity, Net Profit Margin have an effect on stock prices . } \\
\text { Based on the coefficient of determination of the influence of Debt Equity Ratio, Return } \\
\text { On Equity, Net Profit Margi has an influence of } 54.6 \% \text {. It is recommended that }\end{array}$ \\
\hline $\begin{array}{l}\text { Keywords: } \\
\text { Debt of Equity ratio, Return On } \\
\text { Equity, Net Profit Margin, } \\
\text { Stock price }\end{array}$ & $\begin{array}{l}\text { investors and potential investors if they want to invest are expected to be able to see } \\
\text { and analyze the ratios that affect the overall stock price. } \\
\text { Thisisan open accessarticleundertheCC BY-SAlicense. }\end{array}$ \\
\hline $\begin{array}{l}\text { CorrespondingAuthor: } \\
\text { Ono Tarsono, } \\
\text { Economics College of Indonesia, } \\
\text { Jakarta, Indonesia } \\
\text { Email: ono tarsono@gmail.com }\end{array}$ & BY \\
\hline
\end{tabular}

\section{INTRODUCTION}

One of the investment places that can be used by investors to make investments other than in banks or tangible investments such as gold or land is investment in the capital market (Aryanti and Andesta, 2016). The capital market is a complement to the financial sector for two financial financial institutions, where the capital market provides its services as a bridge between capital owners (investors) and borrowers of funds (Brigham and Houston, 2010).

The capital market is one of the means to collect long-term economic resources available to the community. The financial sector of the capital market provides two functions, namely the economic function and the financial function. The capital market as an institution that provides and facilitates various financial instruments that can be traded has a large role in the economy of a country, so it is not surprising that many economists assess a country's economic progress based on capital market activities ( Ekananda, 2019).

The presence of the capital market increases the choice of sources, especially long-term funds for companies, so as to increase the company's ability to determine the optimal capital structure ( Sartono, 2016). One form of investment in the capital market is investing in stocks. Before investing in stocks, individuals or organizations must ensure that the investments made are appropriate. This means that he has to judge from various alternatives that will bring profits in the future, both in the form of dividends, namely returns / income based on the profits obtained by the company whose shares we own, as well as in the form of capital gains, namely the excess of the selling price of the purchase price of the shares. ( Rimbani, 2013).

In addition to gaining profits, shares also contain risks. The risks faced by investors with their share ownership ( Tandelilin, 2011 ) are: not receiving dividends, capital loss, companies going bankrupt or liquidating, shares being delisted from the Stock Exchange.

The stock price also reflects the value of a company, if the company achieves good performance, then the company's shares will be in great demand by investors. The good achievements achieved by the company can be seen in the financial statements published in a certain period. This financial report is very useful for investors to assist in making investment decisions, such as selling, buying, or investing shares (Haholongan, 2021 ).

The thing that must be considered by an investor if he wants to invest in stocks is the level of profit obtained and the level of risk that may occur. There are three types of investors in relation to decision making, namely investors 
who like high risk ( risk seeker ), investors who do not like risk, and investors who are neutral (risk neutral). The nature of investors in general does not like risk ( Hutapea and Tulung, 2017 ).

Investors have various considerations to decide on a stock investment in the capital market. Stock price fluctuations are erratic and contain risks causing uncertainty for investors in determining their investment decisions. Other factors that also influence stock prices are macroeconomic factors of a country such as economic growth, inflation, political stability factors and security factors. A country that cannot guarantee security for investors to invest in a country can reduce the level of investor confidence in investing so that it can affect the performance of the capital market, especially will affect stock prices ( Jufrizen and Fatin, 2020 ).

The level of interest of an investor in investing in shares is influenced by the quality of the value of shares in the capital market. The high and low share value is reflected in the company's performance which is reflected in the financial performance of a company ( Gunawan, 2020).

Debt to Equity Ratio (DER) is a debt ratio used to measure the ratio between total debt and total equity ( Coal, 2017 ).Return on Equity (ROE) is an important ratio for owners and shareholders because this ratio shows the company's ability to manage capital from shareholders to obtain net income ( Muslih and Bachri, 2020). Net Profit Margin (NPM) is the ratio between net profit after tax and total sales. With a net profit margin, it can be seen the amount of net profit earned by the company on every sale made (Egam and Pangerapan, 2017 ).

Efforts to formulate a way to calculate stock prices are carried out by analysis with the aim of getting a satisfactory return by taking into account the factors that affect the stock price. ( Sar and Jufrizen, 2019). In analyzing stock prices there are two methods that are often used, namely Technical Analysis and Fundamental Analysis.

\section{THEORETICAL FOUNDATION}

The share price is the price of a share prevailing in the current market on the stock exchange (Haholongan, 2021). Meanwhile, according to Brigham and Houston (2010), stock prices are prices that occur on the stock market at a certain time and the stock price is determined by market participants. The high and low price of these shares is determined by the demand and supply of these shares in the capital market.

Stock prices can be divided into several categories, namely (Ramadhani, 2017):

a) The nominal price is called the par value

The nominal price is the price listed in the share certificate determined by the issuer to value each share issued.

b) Prime Price

Initial price is the price before the shares are listed on the stock exchange. The initial price depends on the agreement between the issuer and the underwriter.

c) Market Price (market value)

The market price is the selling price from one investor to another, occurring after the shares are listed on the stock exchange.

d) Bookkeeping Prices

The book price is the price asked by the seller or buyer at the end of the trading day.

e) Lowest Price

The lowest price is the price of the lowest stock transaction that occurs on the stock exchange.

f) Average price

The average price is the average price of the highest and lowest prices.

The stock price is a reflection of the value of a company for investors. The better a company manages its business in obtaining profits, the higher the value of the company in the eyes of investors. A fairly high stock price will provide a return for investors in the form of capital gains which in turn will also affect the company's image. The value of a stock is determined by the fundamental condition of the company. Stock prices that occur are the result of market mechanisms, which depend on the strength of supply and demand prices.

There are several factors that can affect stock price fluctuations in the capital market, this happens because stock prices can be influenced by external factors from the company and company internal factors. According to Riyanto (2011) stock prices are influenced by several main factors, namely internal factors and company external factors.

The company's internal factors that affect stock prices are:

1) All financial assets of the company, including shares in generating cash flow.

2) When cash flow occurs, this means the receipt of money or profit to be reinvested to increase additional profits.

3) Acceptable cash flow risk level.

Meanwhile, external factors that can affect stock prices are legal restrictions, general level of economic activity, tax laws, interest rates and stock market conditions.

Debt To Equity Ratio (DER) is a comparison between total liabilities and shareholder equity. Rambe, et all (2017) stated that "Debt to equity ratio is a financial ratio indicating the relative proportion of shareholders equity and debt 
International Journal of Social Science (IJSS)

Vol.1 Issue.4 December 2021, pp: 393-398

ISSN: 2798-3463 (Printed) | 2798-4079 (Online)

used to finance a company's assets". Debt to Equity Ratio is a financial ratio that compares total debt with shareholder equity. It can be concluded that the Debt to Equity Ratio is one of the financial ratios, where this ratio compares the company's total liabilities and shareholder's equity.

$$
\text { DebttoEquityRatio }(\text { DER })=\frac{\text { TotalKewajiban }}{\text { EkuitasPemegangSaham }}
$$

Another measurement of company performance is the return on owner's equity which is commonly known as return on equity (ROE). This Return On Equity (ROE) compares net profit after tax (less common stock dividends) with the equity that has been invested by shareholders in the company (Tandelilin, 2011).

According to Ramadhani, (2017) Return on Equity (ROE) is one of the main tools investors use most often in valuing a stock. Return On Equity (ROE) can be formulated as follows:

$$
\text { Return On Equity }(\text { ROE })=\frac{\text { Laba Bersih Setelah Pajak }}{\text { Modal Sendiri }}
$$

Net Profit Margin is the ratio between net profit (net profit) after deducting all expenses including taxes compared to sales (Sujarweni, 2017). The higher the Net Profit Margin (NPM) will indicate the higher efficiency, so this variable is an important factor that must be considered. One of the decision support tools for buying shares is the net profit margin ratio which is used to measure the company's efficiency (Nainggolan, 2019). Mathematically, NPM can be formulated as follows (Fahmi, 2017).

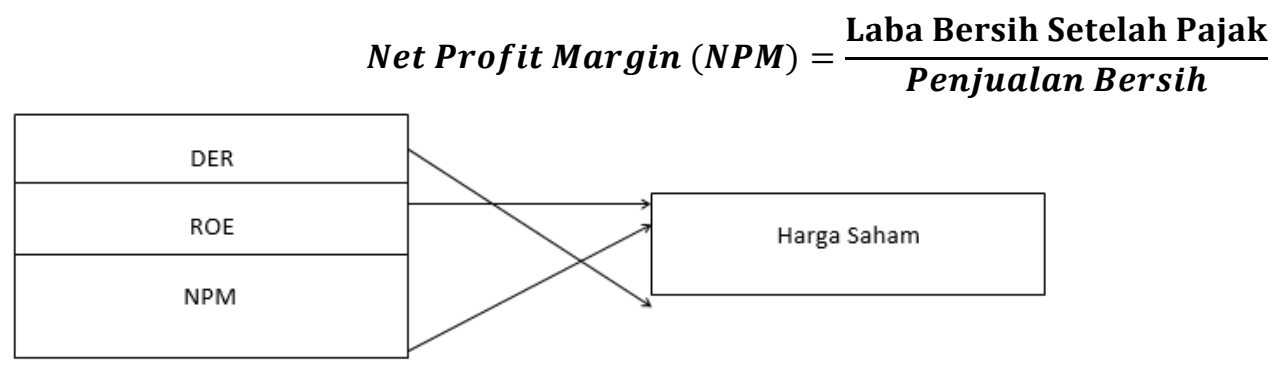

Figure 1. Research Framework

\section{RESEARCH METHOD}

The sampling technique was carried out using the purposive sampling method, namely the method by taking samples based on certain criteria. Companies selected as samples in this study are companies that have the following criteria:

1) Registered as a member and trades its shares through the Indonesia Stock Exchange (IDX).

2) Provide periodic reports to the Indonesia Stock Exchange (IDX) during 2015-2019.

3) Companies whose shares are still actively traded during the study period.

4) There is completeness of published financial report data so that it can be used for the variables used in the study.

5) Presentation of the company's financial statements in rupiah currency.

The total populations of Manufacturing Companies that meet the criteria are 27 companies listed on the Indonesia Stock Exchange in 2015-2019. The type of data used in this study is a document in the form of a document format, for example books, journals, and company annual financial reports that have been audited and published by Manufacturing Companies in 2015-2019. The method of analysis will be carried out, namely multiple linear regressions, determination, $\mathrm{T}$ and $\mathrm{F}$ tests to see the accuracy of the data and the influence between variables.

\section{RESULTS AND ANALYSIS}

Table 1 Hypothesis Test

\begin{tabular}{|l|c|c|c|c|}
\hline \multirow{2}{*}{ Description } & \multicolumn{2}{|c|}{ T Test } & \multicolumn{2}{c|}{ F Test } \\
\cline { 2 - 5 } & T Count & Sig & F Count & Sig \\
\hline DER & 2.485 & 0.014 & 54.656 & 0,000 \\
\hline
\end{tabular}




\begin{tabular}{|l|l|l|l|} 
ROE & 2.779 & 0.006 & \\
\hline NPM & 8.963 & 0.000 & \\
\hline Coefficient Of Determination & \multicolumn{3}{|c|}{0.546} \\
\hline
\end{tabular}

Debt Equity Ratio (DER) has a significant positive effect on the stock price of Manufacturing Companies Listed on the Indonesia Stock Exchange. Based on the table above, it shows that the t value is 2.485 with a significance of $0.014<0.05$. This means that there is a significant influence between DER on the stock prices of Manufacturing Companies Listed on the Stock Exchange for the 2015-2019 period. This is generally because during the research period there was a recovery from the impact of economic fluctuations, so that many companies' debt equity ratio (DER) became low. The company's capital becomes positive due to changes in the rupiah exchange rate against the dollar and low bank interest, the company becomes easier to pay off its debts with the capital it has. This study is in line with that conducted by Ramadhani, (2017) the Debt Equity Ratio (DER) variable has a significant influence on stock prices. This research is supported by Gunawan (2020) the results of the study show that the Debt Equity Ratio (DER) has an effect on stock prices in non-financial companies listed on the Indonesia Stock Exchange (IDX).

Based on the above, it shows that the $t$ value is 2.779 with a significance of $0.006>0.05$, which means that Return On Equity (ROE) has an effect on stock prices. This means that there is a significant positive effect between Return On Equity (ROE) on the stock price of Manufacturing Companies Listed on the Stock Exchange. This is because there are several manufacturing companies on the Indonesia Stock Exchange whose profits tend to increase. In line with what is done by Jufrizen and Fatin (2020), Return On Equity (ROE) has a significant effect on stock prices

The company's Net Profit Margin (NPM) has a significant positive effect on the stock price of Manufacturing Companies Listed on the Indonesia Stock Exchange. Based on the table above, it shows that the t value is 8,963 with a significance of $0.000<0.05$. This means that there is a significant influence between Net Profit Margin (NPM) on the stock price of Manufacturing Companies Listed on the Indonesia Stock Exchange. Thus, it can be said that the higher the Net Profit Margin value, the higher the stock price will be and conversely, the lower the Net Profit Margin value, the lower the stock price will be.

Research conducted by Aryanti and Andesta (2016) Net Profit Margin (NPM) on stock prices proves that the Net Profit Margin (NPM) variable has a positive and significant effect on stock prices of manufacturing companies listed on the IDX.

\section{CONCLUSION}

Based on the results of the analysis and discussion of previous research, this study concludes that DER, ROE, NPM on stock prices. Together the variables DER, ROE, NPM have an effect of 54.6\%. Investors and potential investors if they want to invest are expected to be able to see and analyze the ratios that affect the overall stock price, don't look at these financial ratios one by one.

\section{REFERENCES}

[1] Aryanti, A., Mawardi, M., and Andesta, S. 2016. The Effect of ROA, ROE, NPM and CR on Stock Returns in Companies Listed in the Jakarta Islamic Index (JII). Journal of I-Finance, 2(2), 54-71.

[2] Batubara, HC 2017. The Effect of Return On Assets (ROA), Return On Equity (ROE), and Debt To Equity Ratio (DER) on Stock Prices in Food and Beverage Companies Listed on the Indonesia Stock Exchange for the 20112015 Period. Scientific Journal of Cohesion, 1(1), 95-103.

[3] Brigham, EF, \& Houston, JF 2010. Fundamentals of Financial Management. Jakarta: Four Salemba.

[4] Ekananda, M. 2019. Investment Management. Jakarta: Erlangga Publisher.

[5] Fahmi, I. 2017. Analysis of Financial Statements. Bandung: CV. Alphabet.

[6] FH Ramadhani, 2017. The Influence of Debt To Equity Ratio (DER), Return On Equity (ROE), and Net Profit Margin (NPM) on Share Prices of Mining Sector Companies Listed on the Indonesia Stock Exchange for the Period 2011-2015, J. Profita, Issue 8, 2017.

[7] Gunawan, A. 2020. The Effect of Current Ratio and Debt to Equitty Ratio on Stock Prices in Plastic and Packaging Companies. Sosek: Journal of Social and Economics, 1(1), 29-40.

[8] HI Ghozali.2018. Application of Multivariate Analysis with IBM SPSS 25 Program, Edition 9. Semarang: Diponegoro University

[9] Hutapea, AW, Saerang, IS, \& Tulung, JE 2017. Effect of Return On Assets, Net Profit Margin, Debt To Equity Ratio, and Total Assets Turnover on Stock Prices of the Automotive Industry. EMBA Journal, 5(2), 541-551.

[10] Jufrizen, J., \& Fatin, IN Al. 2020. The Effect of Debt To Equity Ratio, Return On Equity, Return On Assets And Company Size Towards Company Value In Pharmaceutical Companies. Journal of the Humanities, 4(1), 183195. 
International Journal of Social Science (IJSS)

Vol.1 Issue.4 December 2021, pp: 393-398

ISSN: 2798-3463 (Printed) | 2798-4079 (Online)

DOI: https://doi.org/10.53625/ijss.v1i4.716

[11] Muslih, M., \& Bachri, YM 2020. The Effect of Return On Equity and Net Profit Margin on Share Prices in Plantation Companies Listed on the Indonesia Stock Exchange. Journal of the Humanities, 4(1), 34-45.

[12] Nainggolan, A. 2019. The Effect of EPS, ROE, NPM, DER, PER on Stock Prices in Banking Companies Listed on the Indonesia Stock Exchange for the 2014-2017 Period. Journal of Management, 5(2), 61-70.

[13]Egam, GE, Ilat, V., \& Pangerapan, S. 2017. The Effect of Return On Assets (ROA), Return On Equity (ROE), Net Profit Margin (NPM), and Earning Per Share (EPS) on Share Prices of Companies Which Included in the LQ45 Index on the Indonesia Stock Exchange for the 2013-2015 period, 105-114.

[14] Ramadhani, FH 2017. The Influence of Debt To Equity Ratio (DER), Return On Equity (ROE), and Net Profit Margin (NPM) on Share Prices of Mining Sector Companies Listed on the Indonesia Stock Exchange for the 2011-2015 Period. Profita Journal, 5(8), 1-13.

[15]Rambe, MF, Gunawan, A., Julita, Parlindungan, R., \& Gultom, DK 2017. Introduction to Financial Management. Bandung: Cita Librarian Media.

[16] Rimbani, RP.2013. Analysis of the Effect of ROE, EPS, PBV, DER, and NPM on Share Prices in Real Estate and Property Companies on the Indonesia Stock Exchange (IDX) for the 2011-2013 Period. Journal of Business And Management, 53(12), 182-228.

[17] Riyanto, B. 2011. Fundamentals of Corporate Expenditure. Yogyakarta: BPFE.

[18] R. Haholongan, 2011. The Impact of Macroeconomics on the Composite Stock Price Index in Indonesia, Journal of Economics and Business, Vol. 8 No. September 2, 2021

[19] Sari, M., \& Jufrizen, J. 2019. The Effect of Return On Equity and Debt to Equity Ratio on Stock Prices in Retail Trading Sub-Sector Companies Listed on the Indonesia Stock Exchange for the 2013-period. Journal of the Proceedings of the Master of Management Business Seminar, 1(2), 63-75.

[20] Sartono, A. 2016. Financial Management Theory and Applications. Yogyakarta: BPFE.

[21] Sujarweni, S. 2017. Analysis of Financial Statements. Yogyakarta: New Press Library.

[22] Tandelilin, 2011 Portfolio and Investment Theory and Applications Second Edition. Yogyakarta: KANISIUS 
